\title{
Asbestiform Amphiboles and Cleavage Fragments Analogues: Overview of Critical Dimensions, Aspect Ratios, Exposure and Health Effects
}

\author{
Gaia M. Militello ${ }^{1, *(\mathbb{D})}$, Laura Gaggero ${ }^{1}(\mathbb{D})$ and Sebastiano La Maestra ${ }^{2}(\mathbb{D}$ \\ 1 Department of Earth, Environment and Life Sciences (DISTAV), University of Genoa, Corso Europa 26, \\ I-16132 Genoa, Italy; laura.gaggero@unige.it \\ 2 Department of Health Sciences (DISSAL), University of Genoa, 16132 Genoa, Italy; \\ sebastiano.lamaestra@edu.unige.it \\ * Correspondence: gaiamaria.militello@edu.unige.it
}

check for updates

Citation: Militello, G.M.; Gaggero, L.; La Maestra, S. Asbestiform

Amphiboles and Cleavage Fragments Analogues: Overview of Critical

Dimensions, Aspect Ratios, Exposure and Health Effects. Minerals 2021, 11,

525. https://doi.org/10.3390/ $\min 11050525$

Academic Editors: Emily Sarver and David Cliff

Received: 8 March 2021

Accepted: 14 May 2021

Published: 16 May 2021

Publisher's Note: MDPI stays neutral with regard to jurisdictional claims in published maps and institutional affiliations.

Copyright: (c) 2021 by the authors. Licensee MDPI, Basel, Switzerland. This article is an open access article distributed under the terms and conditions of the Creative Commons Attribution (CC BY) license (https:/ / creativecommons.org/licenses/by/ $4.0 /)$.

\begin{abstract}
The term asbestos refers to a group of serpentine (chrysotile) and amphibole (amosite, crocidolite, anthophyllite, tremolite and actinolite) minerals with a fibrous habit. Their chemicalphysical properties make them one of the most important inorganic materials for industrial purposes and technological applications. However, the extraction, use and marketing of these minerals have been prohibited due to proven harmful effects, mainly involving the respiratory system. In addition to the known six minerals classified as asbestos, the natural amphiboles and serpentine polymorphs antigorite and lizardite, despite having the same composition of asbestos, do not have the same morphology. These minerals develop chemical and geometric (length $>5 \mu \mathrm{m}$, width $<3 \mu \mathrm{m}$ and length: diameter $>3: 1$ ), but not morphological, analogies with asbestos, which is regulated by the WHO. The debate about their potential hazardous properties is open and ongoing; therefore, their morphological characterization has a key role in establishing a reliable asbestos hazard scenario. This review focuses on evaluating the most relevant papers, evidencing the need for a reappraisal. Different in vitro, in vivo and epidemiological studies report information about cleavage fragments with critical dimensions similar to asbestos fibres, but very few works target fragments below $5 \mu \mathrm{m}$ in length. Breathable smaller fibres could have deleterious effects on human health and cannot be disregarded from the risk assessment process. Furthermore, a few studies suggest that the carcinogenic nature of short fibres is not excluded. This review highlights that it is worth investigating the effects of this size range of elongated mineral particles and fibres.
\end{abstract}

Keywords: asbestos; nonasbestiform; environmental exposure; occupational exposure; particle size

\section{Introduction}

Asbestos, a substance included among Group I (carcinogenic to humans), is considered one of the most dangerous types of dust for human health [1]. This generic term refers to a group of six natural minerals represented by hydrated silicates easily separable into thin, flexible fibres, resistant to traction and heat. These minerals can develop a crystalline habit that includes the serpentine asbestiform varieties and some asbestiform varieties of amphiboles.

Chrysotile white asbestos, $\mathrm{Mg}_{3} \mathrm{Si}_{2} \mathrm{O}_{5}(\mathrm{OH})_{4}$, is an asbestos of serpentine. Asbestos belonging to the group of amphiboles are actinolite $\left(\mathrm{Ca}_{2}\left(\mathrm{Mg}, \mathrm{Fe}^{2+}{ }_{5} \mathrm{Si}_{8} \mathrm{O}_{22}(\mathrm{OH})_{2}\right)\right.$, amosite (brown asbestos, the commercial name of the cummingtonite/grunerite series, $\left.\left(\mathrm{Mg}, \mathrm{Fe}^{2+}\right)_{7} \mathrm{Si}_{8} \mathrm{O}_{22}(\mathrm{OH})_{2}\right)$, anthophyllite $\left((\mathrm{Mg}, \mathrm{Fe})_{7} \mathrm{Si}_{8} \mathrm{O}_{22}(\mathrm{OH})_{2}\right)$, crocidolite (blue asbestos, the commercial name of riebeckite, $\left.\mathrm{Na}_{2}\left(\mathrm{Fe}^{2+}, \mathrm{Mg}\right)_{3} \mathrm{Fe}^{3+}{ }_{2} \mathrm{Si}_{8} \mathrm{O}_{22}(\mathrm{OH})_{2}\right)$ and tremolite $\left(\mathrm{Ca}_{2} \mathrm{Mg}_{5} \mathrm{Si}_{8} \mathrm{O}_{22}(\mathrm{OH})_{2}\right)$.

Compared to other silicates, asbestos fibres have extremely small diameters in the micron to nanometre range, thanks to the particular property of separating in a longitudinal direction that generates very fine and potentially inhalable fibres [2]. 
However, amphibole fibres can occur with morphological differences, which confer variable flexibility and mechanical strength but the identical geometric characteristics (length $>5 \mu \mathrm{m}$, width $<3 \mu \mathrm{m}$ ) of asbestos. In general, they are rigid and parallel sided, with very variable dimensional distributions of width-to-length ratios. Minerogenetic conditions are responsible for this variation in crystal habit. Therefore, the fibrous amphibole can have an identical chemical and atomic structure but a diversity of crystalline form or growth habit [3]. Of note, also among serpentine polymorphs, are the fibrous antigorite and lizardite, which sometimes occur very similar in morphology to chrysotile and therefore are not easily distinguishable, especially if associated.

Natural processes (i.e., erosion) and excavation activities contribute to the formation of the elongated mineral particles (EMP) of amphibole and serpentine. The fibres of "asbestoslike" varieties are not yet univocally regulated by health and safety institutions worldwide. The threshold of health risks cannot be defined because the potential hazard is not fully investigated.

According to Boulanger et al. [4], short "asbestos" fibres (SAF) are less pathogenic than long "asbestos" fibres (LAF). On the other hand, a cut-off length of $5 \mu \mathrm{m}$ is used to distinguish short from long asbestos fibres. Nevertheless, the limit value of $5 \mu \mathrm{m}$ in length is not based on scientific evidence but has been determined by comparing data obtained from different research groups.

The reason for these inconsistencies is mainly related to different and dated legislation worldwide. The risk of developing chronic diseases by inhalation of fibres is linked to different factors, such as particle morphology, size, physical-chemical properties, and biopersistence correlated with the crystalline habits and can produce severe consequences to the human respiratory system. Having more constraints on this issue plays an essential role in the risk assessment process. This could influence the final calculation of the asbestos concentration for environmentally monitoring fibres. This overview reveals that we are far from understanding which size dimension is crucial due to contradictory conclusions in the available literature.

\section{Mineralogical vs. Commercial Definitions}

The term asbestos has both mineralogical and commercial uses that often cause misunderstandings. Keywords and debated items among the scientific community are the terms fibrous and asbestiform. The term fibrous is linked to the geometry of the particles. According to the definition of "breathable fibre", the parameters indicated by the World Health Organization (WHO) [5] are length $>5 \mu \mathrm{m}$, width $<3 \mu \mathrm{m}$ and aspect ratio (length of the particles divided by the width, aspect ratio) $>3: 1$. The term asbestiform refers to a specific property in which the mineral is formed by fibrils and possesses high tensile strength or flexibility [6].

In detail, nonasbestiform and asbestiform fibres of amphiboles are mainly different in their morphology but are chemically indistinguishable. Moreover, "Subtle differences in their crystal structure can lead to profound differences in physical properties" [7].

The morphological distinction between the two habits was defined by the National Research Council [8], which identifies asbestiform as a structure characterized by crystals that appear singularly similar to organic fibres, such as cotton or hair, or are made up of bundles composed of many parallel fibres (fibrils). According to the WHO, the nonasbestiform habit is characterized by prismatic crystals, even with an irregular shape, or by crystals with acicular growth, which have the same geometric ratios as fibres.

Therefore, these morphological differences derive from particular crystalline structure changes, which entail profound variations in physical properties [9].

Therefore, in nature there are minerals, such as those belonging to the group of serpentine and amphiboles, which can have a fibrous and asbestiform aspect (Figure 1a,b) or a fibrous but nonasbestiform aspect (Figure 1c,d). 

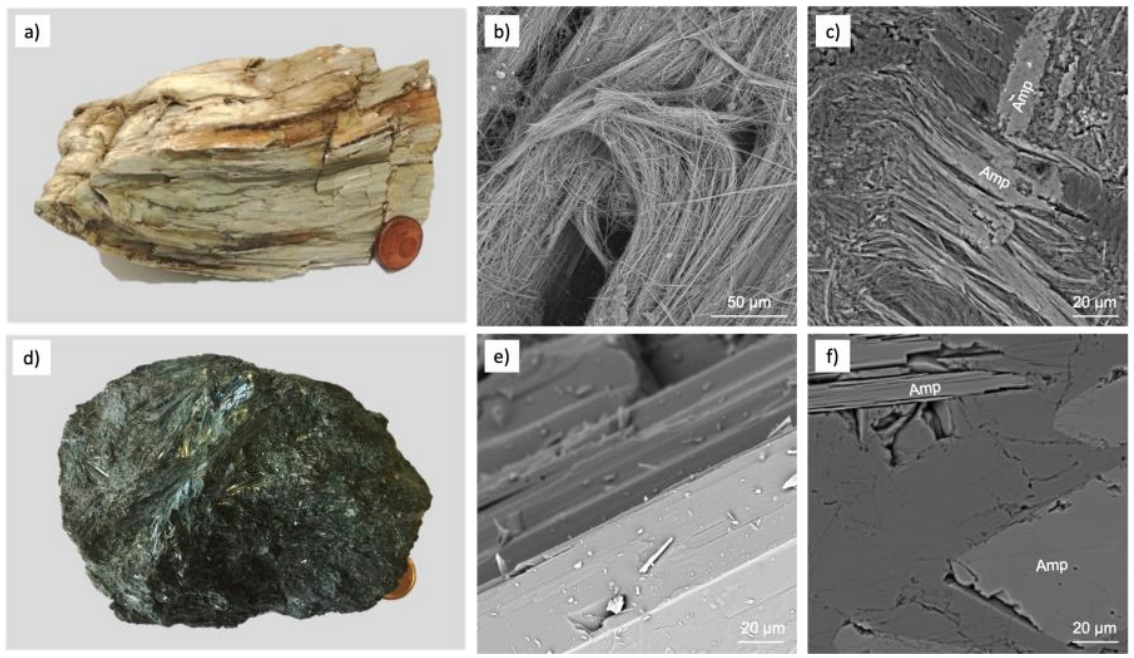

Figure 1. Close up photographs of tremolite-actinolite vein (a) and schist (d). SEM microphotographs of amphiboles (Amp) of the tremolite actinolite series of fibrous and asbestiform habit (b,c) and fibrous but nonasbestiform habit $(\mathbf{e}, \mathbf{f})$. Scale bar in microphotographs; high vacuum: $20 \mathrm{kV}$; detector: back-scattered electrons.

The latter structure has a strong impact on the dimensional distribution of dust after comminution or on the potential carcinogenicity upon inhalation. The scientific community has recently introduced additional terms to clarify any classification misunderstandings. The most common are the following:

- Cleavage fragments: proposed by the Occupational Safety and Health Administration (OSHA) in 1992. It is a term that refers to amphibole (crocidolite, amosite, anthophyllite, tremolite, actinolite) or serpentine (antigorite and lizardite) that, from a morphological point of view, cleave into fragments rather than separate longitudinally into fibrils like asbestos varieties. Therefore, they have the same chemical composition of asbestos species, but in geometrical ratios, they fall within the definition of fibre, although they are not asbestiform. Considering the indexing of crystal faces, monoclinic amphiboles have perfect cleavage along the 110 face, and orthorhombic amphiboles have perfect cleavage along the 210 face [10].

- Elongate mineral particles (EMP): proposed by the National Institute for Occupational Safety and Health (NIOSH) [11] to describe all particles sharing specific attributes, though applicable to a broad class of particle types. In particular, the term refers to mineral particles with a length $\geq 5 \mu \mathrm{m}$ and a minimum aspect ratio of 3:1, which correspond to breathable size [12], avoiding using the term "fibre", which leads to misunderstandings in the definition.

Despite the difficulty of distinguishing between asbestiform and nonasbestiform EMP, the relationship between the size of nonasbestiform EMP and carcinogenic lung disease is still open to interpretation. This description highlights how confusing indications are and that the definition lacks standardised operating definitions for fibres [13].

\section{Studies on Asbestos/Nonasbestos-Related Diseases and Exposure}

The first asbestosis case is dated to 1906, when Dr Montague Murray documented pulmonary fibrosis in a London worker. In 1927, Cook [14] coined the term "pulmonary asbestosis". In 1955, Doll carried out a case-controlled study on textiles, establishing the correlation between exposure to asbestos fibres and lung cancer [15]. Consequently, an increasing number of studies were carried out on different populations, particularly on professionals exposed to asbestos.

The International Agency for Research on Cancer (IARC) declared asbestos a proven carcinogen for humans, placing it in Group 1 (carcinogenic to humans) [1,16]. 
Moreover, the air quality guidelines from the WHO [17] declared that to prevent carcinogenic risk, it is necessary not to exceed a level of asbestos fibre exposure equal to $1 \mathrm{ff}$ / air litre over a lifelong daily exposure. However, there are no threshold limits to date, since any exposure can cause cancer. On the other hand, several studies indicate that morbid risk from asbestos is related to the duration of exposure and cumulative dose $[1,18,19]$.

Although there are specific norms that suggest threshold values to ensure health protection and surveillance, it is noteworthy to highlight that these limits differ not only on a regulatory basis but also in terms of measurement methods and acceptability levels. The recommended exposure limit of asbestos differs according to the examined environment (living environment, working environment). For instance, in working environments, the reference is the limit value of 100 fibres per litre (ff/l) per day, calculated as a normalized average concentration over 8 working hours (L.D. 81/2008). For living environments, reference is the limit value of $20 \mathrm{ff} / 1$ if the fibres are counted by optical phase contrast microscopy (PCOM), while it is $2 \mathrm{ff} / 1$ if these are observed by scanning electron microscopy (SEM, M.D. 06/09/1994). This value agrees with the occupational exposure limit, ruled by Directive 2003/18/EC and Directive/2009/148/EC, for airborne asbestos in workplaces in EU countries [20,21].

According to the $\mathrm{WHO}$, the hazard of asbestos derives from its capability to release breathable fibres. The risk is linked to interconnected factors that control the degree of penetration into the respiratory tract. In fact, morphology, size, physical-chemical properties and biopersistence correlated with the crystalline habits of particles can produce grave consequences to the human respiratory system.

Biopersistence is the main property in the toxicological process, corresponding to the ability of fibres to remain unaltered after their deposition on the pulmonary epithelium. The inhalation and deposition in alveolar spaces directly correlate both with relative length/width ratio and shape. In higher length/width, the fibre is easily inhaled and deposited into the respiratory system. Moreover, the aspect ratio influences the phagocytosis process operated by macrophages. In particular, short asbestos fibres $(<5 \mu \mathrm{m})$ are enclosed in the phagosomes and cleared without triggering chronic inflammation. In contrast, longer fibres $(>5 \mu \mathrm{m})$ cannot be fully engulfed by macrophages and can remain inside the lung for a longer time [22]. The extreme flexibility favours the permanence in the lung environment shown by asbestos fibres. Conversely, cleavage fragments of amphiboles have weaker surfaces that favour breaking by breathing.

Finally, according to the WHO, both chemical composition and surface reactivity increase alveolar macrophage activation. Moreover, the fibre surface can trigger the imbalance of redox status, causing radical species formation and activating the inflammatory process [23]. Fibres act on two different contingents: the mechanical breakdown of the genetic material in the nucleus and the oxidative stress caused by the presence of specific ions, such as iron, in the fibrous mineral. This triggers redox reactions which lead to the breakdown of biological macromolecules, such as DNA. These processes can help each other. On the other hand, the reactive oxygen species (ROS), triggered mainly by the Fenton reaction, results in genotoxic damage underlying the mutagenic events. Asbestos is a complete carcinogen carrying out both initiating and promoting actions [24].

Asbestos has been linked to different pulmonary diseases, such as pleural fibrosis and plaques, asbestosis, benign asbestos pleural effusion, small cell lung carcinoma, nonsmall cell lung carcinoma and malignant mesothelioma. Different mechanisms induced by asbestos (chromosomal alterations, oncogenes activation, loss of tumour suppressor genes, generation of RNOS and direct mechanical damage to cells from asbestos fibres) may be pathways involved in the development of the asbestos-related disease [24,25].

Moreover, workers exposed to asbestos or other powders can be exposed to some other carcinogens, such as diesel engine exhaust, crystalline silica dust, radon gas, nickel compounds, chromium (VI) compounds, arsenic and inorganic arsenic and compounds from cigarette smoke. These people have a significantly greater risk of developing lung 
cancer than people who have only been exposed to asbestos. In a meta-analysis conducted by Ngamwong et al. [26], it was estimated that the odds ratios for lung cancer $(95 \%$ confidence interval (CI)) were 1.70 in asbestos-exposed, 5.65 in smoking and 8.70 in asbestosexposed and smoking, respectively, when compared with lung cancer patients who were not exposed to asbestos and nonsmoking. This study demonstrated an additive synergism for lung cancer with coexposure to asbestos and cigarette smoking.

The effects of the inhalation of nonasbestiform amphiboles are still poorly correlated with asbestos-related diseases. At the OSHA and Mine Safety and Health Administration meeting, the NIOSH confirmed that despite the similarity in size, shape and equal composition between asbestos and nonasbestiform amphiboles, it is necessary to clarify the possible health effects of the latter. Thus, cautiously, NIOSH concluded that there is no evidence to exclude cleavage fragments from the current regulations. The Environmental Protection Agency (EPA) has stated that it would be prudent to assign equivalent relevance for cleavage fragments and fibres in cancer risk [27]. However, the USA occupational regulations do not currently cover asbestiform amphiboles. Therefore, it is crucial to determine whether amphibole cleavage fragments differ sufficiently from asbestos fibres to pose different health risk levels by examining fibre dimensions and shape, which influence respirability, and fibre biopersistence, which influences carcinogenicity [28]. The few studies on cleavage fragments in the literature denote insufficient knowledge at present.

\section{Potential Health Effects of Elongated Mineral Particles}

According to the $\mathrm{WHO}$, the particles of amphiboles and serpentine groups can be defined as fibrous when having a length $>5 \mu \mathrm{m}$, width $<3 \mu \mathrm{m}$ and length/width $>3: 1$. Moreover, in terms of dimension, fibres are considered inhalable when having a diameter between 10 and $100 \mu \mathrm{m}$, while the thoracic fibres have a diameter between 4 and $10 \mu \mathrm{m}$ (Figure 2). These typically are stopped in upper and lower airways. Conversely, the fraction with a diameter $<3 \mu \mathrm{m}$ (respirable fraction) can reach the alveolar space, triggering inflammation and the recruitment of inflammatory cells.

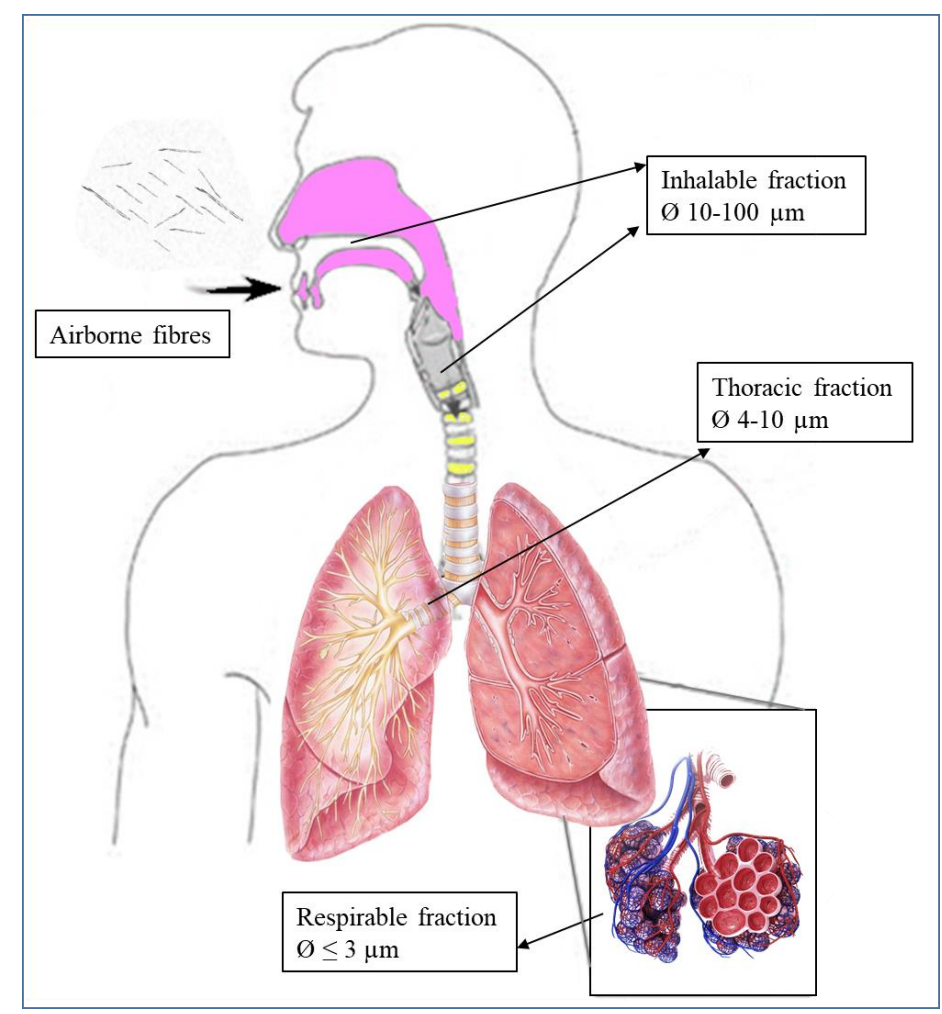

Figure 2. Size-selective inhalation of airborne fibres involves specific regions of the respiratory tract. 
Different studies conducted in vitro and in vivo showed that particles not covered by the dimensions suggested by the WHO could even trigger pathological effects when inhaled or ingested. In this respect, from the beginning of the 1970s, several studies have been conducted considering amphiboles with different geometrical ratios (Table 1). However, few in vivo and in vitro studies have been conducted on the fibrous varieties of antigorite and lizardite.

Table 1. Synoptic table showing fibre dimensions that are the most liable to contribute to lung cancer risk.

\begin{tabular}{|c|c|c|c|c|c|}
\hline \multirow{2}{*}{ Mineral Type } & \multirow{2}{*}{ Study Types } & \multicolumn{3}{|c|}{ Critical Size of Fibres } & \multirow{2}{*}{ References } \\
\hline & & Length & Width & Aspect Ratio & \\
\hline Actinolite & In vivo & $<0.2 \mu \mathrm{m}$ & - & $3: 1$ & [29] \\
\hline Not specified & $\begin{array}{c}\text { Mathematical } \\
\text { model }\end{array}$ & $>1.5 \mu \mathrm{m}$ & $<0.25 \mu \mathrm{m}$ & $3: 1$ & [30] \\
\hline Crocidolite & In vivo & $>3 \mu \mathrm{m}$ & - & $3: 1$ & [31] \\
\hline Not specified & Observational & $\leq 5 \mu \mathrm{m}$ & $\leq 0.25 \mu \mathrm{m}$ & $3: 1$ & [32] \\
\hline Tremolite & In vivo & $>5 \mu \mathrm{m}$ & $\leq 0.5 \mu \mathrm{m}$ & $3: 1$ & [33] \\
\hline Not Specified & Observational & $<5 \mu \mathrm{m}$ & $<3 \mu \mathrm{m}$ & $3: 1$ & [34] \\
\hline Tremolite and other & In vivo & $>5 \mu \mathrm{m}$ & - & $3: 1$ & [35-39] \\
\hline EMP Amphiboles & In vitro & $>8 \mu \mathrm{m}$ & $<0.25 \mu \mathrm{m}$ & $3: 1$ & [40] \\
\hline Tremolite and other & In vitro & $>10 \mu \mathrm{m}$ & - & $3: 1$ & {$[6,35,36,41,42]$} \\
\hline Tremolite & In vivo & $>10 \mu \mathrm{m}$ & $<0.5 \mu \mathrm{m}$ & $3: 1$ & [39] \\
\hline Not specified & In vivo & $>20 \mu \mathrm{m}$ & $<1 \mu \mathrm{m}$ & $3: 1$ & [43] \\
\hline EMP & Cohort studies & $>40 \mu \mathrm{m}$ & $<3 \mu \mathrm{m}$ & $3: 1$ & [44] \\
\hline Asbestos group & Meta-analysis & - & $<0.4 \mu \mathrm{m}$ & $3: 1$ & [45] \\
\hline
\end{tabular}

Different studies indicate that short respirable particles that can not be considered fibres because they do not fall within the dimensions suggested by the WHO can trigger pathological injuries, such as mesothelioma, lung cancer and asbestosis [46-48].

Opinions diverge and are essentially divided into two positions. Some authors assert that nonasbestiform amphibole fibres are not potentially carcinogenic. In contrast, other authors suggest the carcinogenic potential of these fibres. Davis et al. [33] studied the Italian nonasbestiform tremolite effect from Ala di Stura in rats compared to the asbestiform variety. Ala di Stura tremolite contains a subgroup of very long and fine asbestiform fibres and is described as the correspondent nonasbestos variety of tremolite, which would not be expected to cause tumours. However, the high tumour rate observed in the rats has suggested that nonasbestiform and asbestiform amphiboles indeed have similar carcinogenicity. In particular, two-thirds of the rats exposed to the Ala di Stura tremolite developed mesothelioma, but very late in life (median survival time was 755 days). In contrast, the three asbestos samples induced much shorter median survival times, ranging from 301 days to 428 days.

Suzuki et al. [32] analysed lung and mesothelial specimens from human patients and observed that amphibole particles shorter than $5 \mu \mathrm{m}$ and thinner than $0.25 \mu \mathrm{m}$ were strongly associated with neoplasms.

Adib et al. [34] examined the lungs of asbestos-exposed workers with asbestosis, lung cancer or mesothelioma, finding about $50 \%$ of particles, including chrysotile, with length $<5 \mu \mathrm{m}$ and about $20 \%$ of fibres with length $>5 \mu \mathrm{m}$, width $<3 \mu \mathrm{m}$ and aspect ratio $>$ 3:1.

Donaldson et al. $[35,36]$ explored the effects induced in mice by intraperitoneal administration of single doses of amosite samples with fibres longer than $5 \mu \mathrm{m}$ and amosite samples with particles shorter than $5 \mu \mathrm{m}$ (with $\mathrm{A} / \mathrm{R}>3: 1$ for both categories). The different samples were injected in equal amounts. Results showed that a single dose of particles shorter than $5 \mu \mathrm{m}$ injected in mice by intraperitoneal did not trigger local inflammation, but repetitive exposures increased the inflammatory reactions.

Dement et al. [44] showed that exposure to amphiboles with lengths ranging from $<1.5 \mu \mathrm{m}$ to $>40 \mu \mathrm{m}$ and widths ranging from $<0.25 \mu \mathrm{m}$ to $>3.0 \mu \mathrm{m}$ were highly associated 
with developing lung cancer and asbestosis. Moreover, further studies indicate that short particles can contribute to pathological injuries, such as mesothelioma, lung cancer and asbestosis [46-48]. Dodson et al. [49] suggested that particles shorter than $5 \mu \mathrm{m}$ could trigger pathologic mechanisms, such as cancer, and suggested including these particles as a possible risk factor for human health.

Wagner et al. [31] showed that fibre persistence in the lungs of rats exposed to long fibres $(3-6 \mu \mathrm{m}$ and $>6 \mu \mathrm{m})$ and short particles $(3-5 \mu \mathrm{m})$ of crocidolite, increased over 365 days post inhalation for both classes.

On the other hand, different studies reported no evidence when elongated mineral particles were tested with different models. According to the Stanton hypothesis [40], fibres longer than $8 \mu \mathrm{m}$ and thinner than $0.25 \mu \mathrm{m}$ must be considered more dangerous for health. Nevertheless, even nonasbestiform fibres with "Stanton size" cannot be removed by phagocytic cells like macrophages, triggering the typical asbestos-induced pathobiological mechanisms, such as the generation of free radicals, cell and DNA damage, chronic inflammatory reactions and the delivery of chemical carcinogens [50].

The cell culture studies conducted by Donaldson et al. [35,36], Brown et al. [41] and Hill et al. [42] have generally confirmed that particles shorter than $5 \mu \mathrm{m}$ have little pathologic effect, contrary to what might be expected from a general respirable silicate mineral dust.

Timbrell et al. [51] and Wylie et al. [52] reported low cytotoxicity in culture cells exposed to nonasbestiform tremolite. The health effects due to asbestos short particle exposure were examined by Pott et al. [29], who reported that 56\% of rats had lung tumours and pleural mesotheliomas after intraperitoneal injection of asbestos actinolite. The size distribution showed that $90 \%$ of the asbestos particles had a length $<0.2 \mu \mathrm{m}$ and $10 \%<4.2 \mu \mathrm{m}$. In contrast, when a similar dose of nonasbestiform actinolite was used, no tumours were found [29,53,54]. Berman et al. [37] suggested that asbestos fibres longer than $5 \mu \mathrm{m}$ contributed to lung tumour development, as opposed to those shorter than $5 \mu \mathrm{m}$. Wylie et al. [55] exposed animals to asbestos and nonasbestos fibres. The asbestos fibres had diameters thinner than $1 \mu \mathrm{m}$, and nearly $90 \%$ were thinner than $0.5 \mu \mathrm{m}$. In contrast, about half of the nonasbestos amphibole particles were thinner than $1 \mu \mathrm{m}$, only $20 \%$ of which were thinner than $0.5 \mu \mathrm{m}$. Results showed that tumours in the exposed animals were proportional to the log of the dose of fibres thinner than $1 \mu \mathrm{m}$.

A similar study [42], in which the authors used the same minerals, reported a significant release of superoxide anions by macrophages. These results support the view that fibre length is crucial in determining pathogenicity, since this factor is associated with the development of inflammation, pulmonary fibrosis and tumour formation. Goodglick and Kane [38] evaluated the cytotoxicity on macrophages of mice by using crocidolite with long fibres $(\mathrm{L}>5 \mu \mathrm{m})$ and short particles $(\mathrm{L} \leq 5 \mu \mathrm{m})$. Although a comparison based on the number of fibres showed lower toxicity for the short fibres, cytotoxicity was demonstrated for both types of samples. However, the authors considered that these differences in effect were substantially dependent on iron content in the samples, as pretreatment by a chelating agent inhibited the toxicity. Riganti et al. [56] compared the effects of long asbestos fibres $(\mathrm{L}>5 \mu \mathrm{m}(70 \%)$ and $<2 \mu \mathrm{m}(25 \%))$ and short amosite particles $(\mathrm{L}<5 \mu \mathrm{m}(98 \%)$ and $<2 \mu \mathrm{m}$ $(75 \%))$ on human epithelial cells. A higher effect was evidenced from the long asbestos fibre sample, generating free radicals and inhibiting glucose metabolism on A549 cells.

Davis et al. [39] exposed rats for six months to the injection of samples with elongated mineral particles and long fibres of amosite. The first group of samples contained about $0.1 \%$ of fibres longer than $10 \mu \mathrm{m}$ and about $2 \%$ longer than $5 \mu \mathrm{m}$, while the second group contained more than $11 \%$ of fibres longer than $10 \mu \mathrm{m}$ and $3 \%$ longer than $25 \mu \mathrm{m}$. The diameter distributions were very similar: about $50 \%$ less than $0.5 \mu \mathrm{m}$ in width. The experiments produced mesothelioma in $88 \%$ and $95 \%$ of rats treated, respectively, with 10 and $25 \mathrm{mg}$ powders of long asbestos fibres. Simultaneously, the short fibres of asbestos produced $0 \%$ and $4 \%$ tumours with the same respective doses. Moreover, experiments conducted with other minerals suggest that fibres exceeding $20 \mu \mathrm{m}$ and thinner than $1 \mu \mathrm{m}$ 
are necessary to cause cancer. According to the authors, this probably happens because the long fibres cannot be phagocytised by macrophages or removed from the lungs [43].

In 1982, Wagner et al. [57] tested three samples of asbestos tremolite in different cell lines, showing that longer fibres induced enzymatic release of LDH and BGL when treating the peritoneal macrophages of mice and caused the formation of giant cells in the A549 cell. Berman et al. [58] showed that tumour generation is related to the concentration of fibres longer than $40 \mu \mathrm{m}$ but acknowledged that an aspect ratio of 20:1 or greater should eliminate most of the asbestos and nonasbestos particles. This information was incorporated into a new risk model protocol that considers only the concentration of fibres longer than $10 \mu \mathrm{m}$ and thinner than $0.4 \mu \mathrm{m}$, not differentiating between asbestiform and nonasbestiform fibres. Long-term inhalation studies were performed in hamsters using the "nose only" method of exposure to amosite samples with lengths $>5 \mu \mathrm{m}$ and $>20 \mu \mathrm{m}$. The numbers of amosite fibres did not decrease at low $\left(0.8 \mathrm{mg} / \mathrm{m}^{3}\right)$ and medium doses, and no difference in the retention rate between the two groups of fibres with different lengths was detected at the highest dose [59].

Although many studies have considered fibre length as a determinant of pathogenicity, expressing differing opinions, other authors reported the necessity of further studies to elucidate the importance of the geometric ratio of fibre [60].

Gamble and Gibbs [28], in agreement with Addison et al. [54], summarized the health effects of nonasbestos amphiboles. The health studies indicate the necessity of correctly identifying asbestos fibres. The authors argue that relying solely on the aspect ratio of the particles to classify them as asbestos will lead to significant errors. They addressed amphibole particles with aspect ratios of at least 3:1, as defined in many analytical procedures. This classification involves an overestimation, including the nonasbestos amphibole and byssolite samples as asbestos, leading to a considerable risk overvaluation. Mossman et al. [61], commenting on the size distribution data from Wylie et al. [55], suggested that cleavage fragments are less bioreactive and cytotoxic than asbestiform fibres. Later, Mossman et al. [62] recognized that the possible role of fibres $<5 \mu \mathrm{m}$ cannot be ruled out.

Berman and Crump [45] extended the Stanton hypothesis to create a risk model based on long fibres thinner than $0.4 \mu \mathrm{m}$, showing a relationship between disease and the concentration of long-thin asbestos fibres. Chatfield et al. [63] proposed a protocol that defined asbestiform as only those fibres whose widths range from $0.04 \mu \mathrm{m}$ to $1.5 \mu \mathrm{m}$ and whose aspect ratios range from 20 to 1000. Accordingly, elongated particles out of these ranges are considered nonasbestiform.

Belardi et al. [64] reported no epidemiological evidence in cancer development from cleavage fragment exposure. In contrast, epidemiological studies [30,65-68] showed that higher lung cancer rates are attributable to long fibre exposure. Perhaps the authors did not provide any definitive conclusions for the other size classes. In fact, they observed that short-thin fibres represented the majority of fibres counted by transmission electron microscopy. However, they did not determine whether the association of short fibres with lung cancer is a spurious effect or it evidences that short fibres play a specific role in carcinogenesis.

\section{Regulatory Framework}

The evaluation of the asbestos hazard is based on counting criteria used to determine the number of regulated fibres in bulk materials. The approach to quantification and analysis is not univocal $[69,70]$. From this perspective, different procedures were proposed for refining the classification of particles as asbestos or fibres originated by preferential cleavage of particles. There are mainly two opposite concepts of classification in the national and international regulatory frameworks, and therefore variable concern about the particles [6]:

- $\quad$ The NIOSH and the USA Environmental Protection Agency (EPA) [71] propose a very cautious approach favouring exposed workers. Therefore, quantification methods of asbestos (Method 7400 ' $\mathrm{A}$ ' and ' $\mathrm{B}$ ') are much more stringent [72,73]. In fact, to some 
scientific community members, any very thin and long mineral with a high aspect ratio can be called fibrous ([74] and references within). NIOSH, OSHA, the WHO and the EPA favour including cleavage fragments within fibre counts, taking into account length and diameter.

- The American Society for Testing and Materials (ASTM) restricts the counting field only to those mineral phases whose appearance meets the specific characteristics (curvature, flaking, presence of fibrils at the apex of the beam) described by NIOSH and length $>10 \mu \mathrm{m}$ or width $<1 \mu \mathrm{m}$ [75].

\section{Counting Criteria and Cleavage Fragments}

Worldwide, there is thus a regulatory and scientific gap concerning the classification criteria of asbestos. A particle's classification as asbestiform mineral or a cleavage fragment (nonasbestiform) has a crucial role in assessing a reliable asbestos hazard scenario.

To date, classification systems are generic, subjective and not always applicable to amphiboles. No clear boundary allows discriminating between the fibrous and asbestiform amphiboles (i.e., from their crystallization) and those attaining critical dimensions after the comminution of an acicular crystal. In the first case, the amphibole can have a morphology similar to the chrysotile (Figure 3a,b). The second case appears as cleavage fragments (Figure $3 c, d$ ), along with the systems of cleavage traces, with dimensions and geometric ratios that make it classifiable as asbestos.
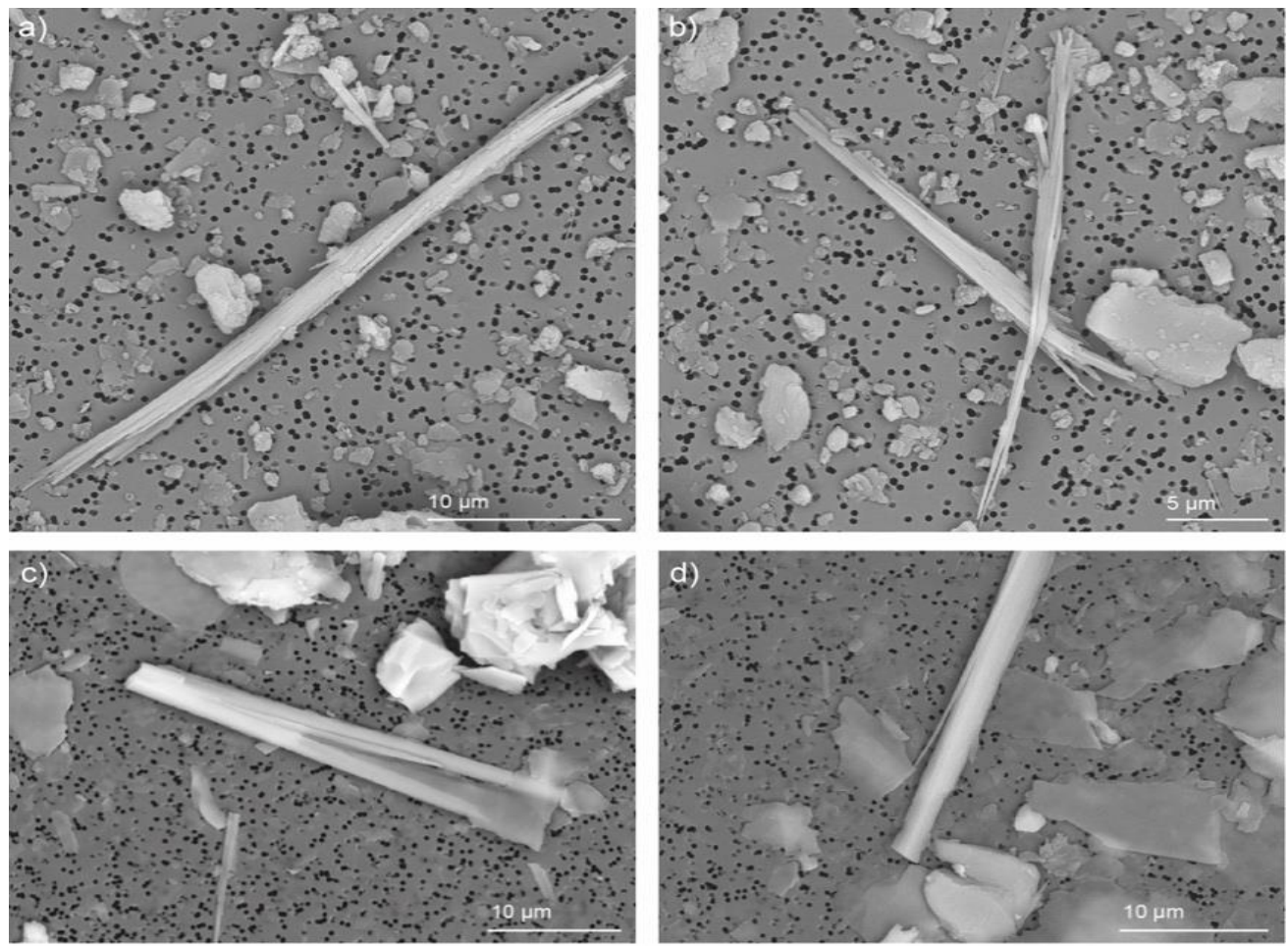

Figure 3. SEM images. Representative asbestiform $(\mathbf{a}, \mathbf{b})$ and nonasbestiform $(\mathbf{c}, \mathbf{d})$ amphiboles of the tremolite-actinolite series. Magnifications: 2000×; high vacuum: $20 \mathrm{kV}$; detector: back-scattered electrons.

Often, asbestiform fibres and cleavage fragments of the same mineral show a significant overlap in the aspect ratio, making it clearly difficult to distinguish between asbestiform fibres and cleavage fragments using aspect ratio alone. Currently, there is no agreement on making such a distinction [60]. 
According to ANSES [76], there is no rationale to distinguish between nonasbestiform amphiboles and asbestiform amphiboles with reference to their health effects in the current state of knowledge.

Based on the results reported by in vitro and in vivo tests and epidemiological studies, some of the same authors have proposed dimensional parameters for the count of fibres (when originated by preferential cleavage fragments) quantitative analysis phase. The most accredited counting criteria worldwide are listed below (Table 2).

Table 2. Counting criteria adopted for asbestos identification procedures from different countries or institutions. $\mathrm{L}=$ length; $\mathrm{D}=$ diameter; $\mathrm{A} / \mathrm{R}=$ aspect ratio [Modified from 6].

\begin{tabular}{ccc}
\hline Country & Single Particle & Reference \\
\hline South Africa & $\mathrm{L}>8 \mu \mathrm{m} ; \mathrm{D}<0.25 \mu \mathrm{m}$ & {$[40]$} \\
N. A. & $\mathrm{A} / \mathrm{R} \geq 5: 1$ & {$[77]$} \\
N. A. & $\mathrm{A} / \mathrm{R} 20: 1-100: 1$ & {$[71]$} \\
N. A. & $\mathrm{L}>10 \mu \mathrm{m} ; \mathrm{D}<0.4 \mu \mathrm{m} ; \mathrm{A} / \mathrm{R}>25: 1$ & {$[78]$} \\
Libby & $\mathrm{D}<0.5 \mu \mathrm{m} ; \mathrm{A} / \mathrm{R} 20: 1-100: 1$ & {$[63]$} \\
Brazil, Colorado, Labrador & $\mathrm{D}<1.5 \mu \mathrm{m} ; \mathrm{A} / \mathrm{R}>20: 1$ & {$[3]$} \\
North Carolina, New York, Virginia & $\mathrm{A} / \mathrm{R}>5: 1$ & {$[79]$} \\
Jamestown, North Carolina, South Africa, & $\mathrm{D}<0.5 \mu \mathrm{m} ; \mathrm{A} / \mathrm{R}>16: 1$ & \\
Italy, Libby, Austria, Gouverneur, West & & {$[75]$} \\
Greenland, Homestake, Shinness & $\mathrm{D}<1 \mu \mathrm{m}$ & \\
N.A. & & \\
\hline
\end{tabular}

Aspect ratio is the main feature used to differentiate asbestiform fibres from nonasbestiform particles. Several aspect ratio values have been suggested as cut off for the two categories ranging from 3:1 to 5:1, to 20:1 or greater. Wylie et al. [55] showed that the average aspect ratio in asbestos fibres is 8-10 times greater than in nonasbestos particles [6,55].

The Asbestos Hazardous Emergency Response Act method (AHERA method) [77] suggests the ratio 5:1 as the minimum aspect ratio to consider. The EPA (1993) made a distinction in term of aspect ratio from asbestos and cleavage fragments of the same phases: a range from 20:1 to 100:1 or higher for asbestiform fibres and a ratio $<20: 1$ or lower for cleavage fragments. Berman and Crump [58] proposed an A/R $>25: 1$ and classified asbestos fibres as $\geq 10 \mu \mathrm{m}$ and thinner than $0.4 \mu \mathrm{m}$. For Harris et al. [78], asbestos has very high (20:1 to 100:1 or higher) aspect ratios and very thin fibres (width $\leq 0.5 \mu \mathrm{m}$ ). Moreover, they consider the morphological aspect, such that asbestos has parallel, often curved sides, smooth surfaces and no discernible crystal faces. Conversely, acicular fibres have generally moderate (10:1 to 20:1) to high (>20:1) aspect ratios, thin particles (width $\leq 0.5 \mu \mathrm{m}$ ) and well-developed crystal faces.

Applying the Chatfield [63] procedure for asbestos, A/R must be $>20: 1$ and the width $<1.5 \mu \mathrm{m}$. In Van Orden et al. [3,79] the asbestos samples have an average aspect ratio of $76: 1$ and a width of about $0.27 \mu \mathrm{m}(90 \%$ thinner than $0.5 \mu \mathrm{m})$. Conversely, nonasbestos amphiboles have an average aspect ratio of $16: 1$ and a width of about $0.97 \mu \mathrm{m}(75 \%$ wider than $0.53 \mu \mathrm{m})$. The protocol introduced by Harper et al. [75] is based on microscopic measurements and includes all EMP showing width below $1 \mu \mathrm{m}[6,63]$.

\section{Conclusions}

Our literature review did not reveal strong evidence indicating that cleavage fragments have the same or greater carcinogenic potential than asbestos. Most of the data collected by the different authors suggest that the toxic effect of asbestos fibres increases with length, despite some notable exceptions. However, the extent to which a mineral with an asbestiform habit affects cell behaviour relative to that of a cleavage fragment of the same mineral still remains open to investigation. Moreover, the chemical composition of a particle can influence the pathogenic response of the tissue it comes into contact with. 
For instance, iron content may exacerbate reactive species and inflammation response production.

Different experimental studies show that short asbestos fibres are less active than long asbestos fibres. However, if short asbestos fibres are used in high doses, they can cause inflammation, interstitial pulmonary fibrosis and pleural reactions. Certainly, the different methodologies used for sample preparation, analytical techniques, duration of exposure and postexposure monitoring are discriminating factors.

For health safety purposes, the assessment of asbestos air contamination is carried out considering only the particles with a specific length-diameter ratio (3:1) and a length greater than $5 \mu \mathrm{m}$. The value $5 \mu \mathrm{m}$ as the limit of length was arbitrarily chosen in the 1960s due to the resolution of transmitted optical microscopy in quantitative analysis and because it was fairly consistent with literature data highlighting the role of fibre size in asbestos toxicity.

Indeed, it is true that most risk assessment models have shown that adverse health effects are associated with fibres longer than $5 \mu \mathrm{m}$ or even longer than $10 \mu \mathrm{m}$. Only a few risk assessment models believe that even fibres shorter than $5 \mu \mathrm{m}$ should be considered dangerous, suggesting that they may play a role, albeit one that is much less significant than the effect of longer fibres. No agreement has currently been reached on this distinction. According to Hwang et al. [80], a lack of consensus on the appropriate exposure metric can partially explain the different exposure-response relationships obtained in an epidemiological study. Finally, the potential genotoxicity of nonasbestiform fibres with equal critical size to asbestos have been poorly tested.

International health and safety organizations agree on the absence of a "safe" level of asbestos exposure and agree that it should be minimized. However, reference values are necessary to ensure the protection and surveillance of workers' health. Despite the known carcinogenic nature of asbestos, this topic still remains a controversial issue globally in the science of disease prevention, as debates on health impact, identification criteria and regulatory limits are still ongoing.

There is currently insufficient and contradictory evidence to explain the pathogenic role of cleavage fragments for both amphibole and serpentine.

On the other hand, humans can inhale fibres in diameter $\leq 3 \mu \mathrm{m}$, depositing them in the thoracic and gas exchange regions of the lung. This physiological difference makes the animal study less specific [81], as, e.g., rodents breathe only nasally, inhaling fibres with a diameter $\leq 1 \mu \mathrm{m}$.

Some authors state that the lack of carcinogenic effects of the fibres of the cleavage fragment of amphiboles is due to the failure in reaching the critical dimensions indicated by the WHO for the asbestiform fibre. On the other hand, many studies showed that the size of asbestiform and nonasbestiform elongated particles is often comparable [6]. Therefore, the pathogenicity of the short fibres cannot be completely ruled out, especially in high exposure situations. Further studies are needed to clarify the role of cleavage fragments, especially in cases of occupational exposure.

Author Contributions: Conceptualization, G.M.M., S.L.M. and L.G.; methodology, G.M.M., S.L.M. and L.G.; validation, L.G. and S.L.M.; investigation, G.M.M. and S.L.M.; resources, G.M.M., S.L.M. and L.G.; data curation, G.M.M., S.L.M. and L.G.; writing-original draft preparation, G.M.M., S.L.M. and L.G.; writing-review and editing, G.M.M., S.L.M. and L.G.; supervision, S.L.M. and L.G.; funding acquisition, S.L.M. and L.G. All authors have read and agreed to the published version of the manuscript.

Funding: This work was carried out with the financial support of the "Analisi delle proprietà microstrutturali, chimico-fisiche di materiali inorganici; determinazioni quantitative della composizione mineralogica di materiali naturali e delle proprietà tecniche dei materiali litici" Laboratory funds, DISTAV, University of Genoa.

Data Availability Statement: Data sharing not applicable. 
Acknowledgments: The manuscript greatly benefited of the suggestions from the anonymous reviewers.

Conflicts of Interest: The authors declare no conflict of interest.

\section{References}

1. IARC. Monograph on the Evaluation of the Risk to Human-Asbestos-Supplement 7; IARC Scientific Publication International Agency for Research on Cancer: Lyon, France, 1987.

2. Pisu, R.; Cinus, S.; Demuru, S.; Di Gregorio, A.; Manca, P.; Marras, M.; Perezzani, S. Direttive Generali per La Redazione del Piano Regionale di Protezione, Decontaminazione, Smaltimento e Bonifica Dell'Ambiente ai Fini Della Difesa dai Pericoli Derivanti Dall'Amianto; Regione Autonoma della Sardegna Assessorato della difesa dell'Ambiente: Cagliari, Italy, 2008.

3. Van Orden, D.R.; Allison, K.A.; Lee, R.J. Differentiating amphibole asbestos from non-asbestos in a complex mineral environment. Indoor Built Environ. 2008, 17, 58-68. [CrossRef]

4. Boulanger, G.; Andujar, P.; Pairon, J.C.; Billon-Galland, M.A.; Dion, C.; Dumortier, P.; Brochard, P.; Sobaszek, A.; Bartsch, P.; Paris, C.; et al. Quantification of short and long asbestos fibres to assess asbestos exposure: A review of fibre size toxicity. Environ. Health 2014, 13, 59. [CrossRef] [PubMed]

5. WHO (World Health Organization). The World Health Report 1997-Conquering Suffering, Enriching Humanity; WHO: Geneva, Switzerland, 1997.

6. Militello, G.M.; Sanguineti, E.; Yus González, A.; Gaggero, L. Asbestos amphiboles: Effects of comminution on tremolite and actinolite regulated and unregulated fibres. Episodes 2020, 43. [CrossRef]

7. Ilgren, E.B.; Penna, B.M. The Biology of Cleavage Fragments: A Brief Synthesis and Analysis of Current Knowledge. Indoor Built Environ. 2004, 19, 14. [CrossRef]

8. National Research Council (US). Asbestiform Fibres Nonoccupational Health Risks; National Academies Press (US): Washington, DC, USA, 1984.

9. Langer, A.M.; Nolan, R.P.; Addison, J. Distinguishing between amphibole asbestos fibres and elongate cleavage fragment of their non-asbestos analogues. In Mechanism in Fibre Carcinogenesis; Plenum Press: New York, NY, USA, 1991; pp. $253-267$.

10. Shelley, D. Manual of Optical Mineralogy; Elsevier Scientific Publishing Company: New York, NY, USA, 1975 ; pp. 158-170.

11. National Institute for Occupational Safety and Health. Current Intelligence Bulletin. 2010. Asbestos Fibres and Other Elongate Mineral Particles: State of the Science and Roadmap for Research. Available online: http:/ / www.cdc.gov/niosh/review/public/ 099-C/pdfs / AsbestosRoadmapPublicCommentDraftV4.pdf (accessed on 9 August 2010).

12. Williams, C.; Dell, L.; Adams, R.; Rose, T.; Van Orden, D. State-of-the-science assessment of non-asbestos amphibole exposure: Is there a cancer risk? Environ. Geochem. Health 2013, 35, 357-377. [CrossRef]

13. Keane, M.J.; Stephens, J.W.; Zhong, B.Z.; Miller, W.E.; Wallace, W.E. A study of the effect of chrysotile fibre surface composition on genotoxicity in vitro. J. Toxicol. Environ. Health Part A 1999, 57, 529-541. [CrossRef]

14. Cook, W.E. Pulmonary asbestosis. Br. Med. J. 1927, 2, 1024-1025. [CrossRef] [PubMed]

15. Doll, R. Mortality for lung cancer in asbestos workers. Br. J. Ind. Med. 1955, 12, 81-86. [CrossRef]

16. IARC. Monograph in Evaluation of the Carcinogenic Risk of Chemical to Man. In Asbestos; World Health Organization (WHO): Lyon, France, 1977; p. 106.

17. World Health Organisation. WHO Air Quality Guidelines. In Asbestos, 2nd ed; Regional Office for Europe: Copenhagen, Denmark, 2000.

18. Luberto, F.; Amendola, P.; Belli, S.; Bruno, C.; Candela, S.; Grignoli, M.; Comba, P. Mortality study of asbestos cement workers in Emilia-Romagna. Epidemiol. Prev. 2004, 28, 239-246. [PubMed]

19. Szeszenia-Dabrowska, N.; Wilczyńska, U. Medical monitoring of asbestos-exposed workers: Experience from Poland Beata Świątkowska. Bull. World Health Organ. 2016, 94, 599-604.

20. European Commission. Directive 2003/18/EC and Directive/2009/148/EC, Protection of Workers from the Risks Related to Exposure to Asbestos at Work; European Commission: Brussels, Belgium; Luxembourg, 2009.

21. Gaggero, L.; Sanguineti, E.; Yus González, A.; Militello, G.M.; Scuderi, A.; Parisi, G. Airborne asbestos fibres monitoring in tunnel excavation. J. Environ. Manag. 2017, 196, 583-593. [CrossRef]

22. Ishida, T.; Fujihara, N.; Nishimura, T.; Funabashi, H.; Hirota, R.; Ikeda, T.; Kuroda, A. Live-cell imaging of macrophage phagocytosis of asbestos fibres under fluorescence microscopy. Genes Environ. 2019, 41, 14. [CrossRef]

23. IARC. Biological Agents; IARC Monographs on the Evaluation Carcinogenic Risks to Humans; IARC: Lyon, France, 2012; Volume 100B.

24. La Maestra, S.; Micale, R.T.; Ferretti, M.; Izzotti, A.; Gaggero, L. Attenuation of oxidative stress and chromosomal aberrations in cultured macrophages and pulmonary cells following self-sustained high temperature synthesis of asbestos. Sci. Rep. 2020, 10, 8581. [CrossRef] [PubMed]

25. Solbes, E.; Harper, R.W. Biological responses to asbestos inhalation and pathogenesis of asbestos-related benign and malignant disease. J. Investig. Med. 2018, 66, 721-727. [CrossRef] [PubMed]

26. Ngamwong, Y.; Tangamornsuksan, W.; Lohitnavy, O.; Chaiyakunapruk, N.; Scholfield, C.N.; Reisfeld, B. Additive Synergism between Asbestos and Smoking in Lung Cancer Risk: A Systematic Review and Meta-Analysis. PLoS ONE 2015, 10, e0135798. [CrossRef] 
27. Harper, M. 10th Anniversary Critical Review: Naturally occurring asbestos. J. Environ. Monit. 2008, 10, 1394-1408. [CrossRef] [PubMed]

28. Gamble, J.F.; Gibbs, G.W. An evaluation of the risks of lung cancer and mesothelioma from exposure to amphibole cleavage fragments. Regul. Toxicol. Pharmacol. 2008, 52, S154-S186. [CrossRef] [PubMed]

29. Pott, F.; Roller, M.; Ziem, U.; Reiffer, F.J.; Bellmann, B.; Rosenbruch, M.; Huth, F. Carcinogenicity studies on natural and man-made fibres with the intraperitoneal test in rats. In Non-Occupational Exposure to Mineral Fibres; Bignon, J., Peto, J., Saracci, R., Eds.; International Agency for Research on Cancer: Lyon, France, 1989; pp. 173-179.

30. Hamra, G.B.; Loomis, D.; Dement, J. Examining the association of lung cancer and highly correlated fibre size-specific asbestos exposures with a hierarchical Bayesian model. Occup. Environ. Med. 2014, 71. [CrossRef] [PubMed]

31. Wagner, J.C.; Berry, G.; Skidmore, J.W.; Timbrell, V. The effects of the inhalation of asbestos in rats. Br. J. Cancer 1974, 29, 252-269. [CrossRef]

32. Suzuki, Y.; Yuen, R.; Ashley, R. Short, thin asbestos fibres contribute to the development of human malignant mesothelioma: Pathological evidence. Intern. J. Hyg. Environ. Health 2005, 208, 201-210. [CrossRef]

33. Davis, J.M.G.; Addison, J.; McIntosh, C.; Miller, B.G.; Niven, K. Variations in the carcinogenicity of tremolite dust samples of differing morphology. Ann. N.Y. Acad. Sci. 1991, 643, 473-490. [CrossRef] [PubMed]

34. Adib, G.; Labreche, F.; De, G.L.; Dion, C.; Dufresne, A. Short, fine and WHO asbestos fibres in the lungs of Quebec workers with an asbestos-related disease. Am. J. Ind. Med. 2013, 56, 1001-1014. [CrossRef] [PubMed]

35. Donaldson, K.; Brown, G.M.; Brown, D.M.; Bolton, R.E.; Davis, J.M.G. Inflammation generating potential of long and short fibre amosite asbestos samples. Br. J. Ind. Med. 1989, 46, 271-276. [CrossRef] [PubMed]

36. Donaldson, K.; Szymaniec, S.; Li, X.Y.; Brown, D.M.; Brown, G.M. Inflammation and immunomodulation caused by short and long amosite asbestos samples. In Mecanisms in Fibre Carcinogenesis; Brown, R.C., Hoskins, J., Eds.; Plenum Press: New York, NY, USA, 1991; pp. 121-130.

37. Berman, W.; Crump, K.; Chatfield, E.; Davis, J.; Jones, A. The sizes, shapes, and mineralogy of asbestos structures that induce lung tumors or mesothelioma in AF/HAN rats following inhalation. Risk Anal. 1995, 15, 181-195. [CrossRef] [PubMed]

38. Goodglick, L.A.; Kane, A.B. Cytotoxicity of long and short crocidolite asbestos fibres in vitro and in vivo. Cancer Res. 1990, 50, 5153-5163. [PubMed]

39. Davis, J.M.G.; Addison, J.; Bolton, R.E. The pathogenicity of long versus short fibre samples of amosite asbestos administered to rats by inhalation and intraperitoneal injection. Br. J. Exp. Pathol. 1986, 67, 415-430.

40. Stanton, M.F.; Layard, M.; Tegeris, A.; Miller, E.; May, M.; Morgan, E.; Smith, A. Relation of particle dimension to carcinogenicity in amphibole asbestos and other fibrous minerals. J. Natl. Cancer Inst. 1981, 67, 965-976. [PubMed]

41. Brown, G.M.; Cowie, H.; Davis, J.M.G.; Donaldson, K. In vitro assays for detecting carcinogenic mineral fibres: A comparison of two assays and the role of fibre size. Carcinogenesis 1986, 7, 1971-1974. [CrossRef] [PubMed]

42. Hill, I.M.; Beswick, P.H. Differential release of superoxide anions by macrophages treated with long and short fibre amosite asbestos is a consequence of differential affinity for opsonin. Occup. Environ. Med. 1995, 52, 92-96. [CrossRef]

43. Lippmann, M. Effects of fibre characteristics on lung deposition, retention, and disease. Environ. Health Perspect. 1990, 88, 311-317. [CrossRef] [PubMed]

44. Dement, J.M.; Kuempel, E.D.; Zumwalde, R.D.; Smith, R.J.; Stayner, L.T.; Loomis, D. Development of a fibre size-specific job-exposure matrix for airborne asbestos fibres. Occup. Environ. Med. 2008, 65, 605-612. [CrossRef] [PubMed]

45. Berman, D.W.; Crump, K.S. A meta-analysis of asbestos-related cancer risk that addresses fibre size and mineral type. Crit. Rev. Toxicol. 2008, 38 (Suppl. 1), 49-73. [CrossRef] [PubMed]

46. Cunningham, H.M.; Moodie, C.A.; Lawrence, G.A.; Ponterfract, R.D. Chronic effects of ingested asbestos in rats. Arch. Environ. Contam. Toxicol. 1977, 6, 507-513. [CrossRef] [PubMed]

47. Patel-Mandlik, K.J.; Millette, J.R. Chrysotile asbestos in kidney cortex of chronically gavaged rats. Arch. Environ. Contam. Toxicol. 1983, 12, 247-255. [CrossRef]

48. Weinzweig, M.; Richards, R.J. Quantitative assessment of chrysotile fibrils in the bloodstream of rats which have ingested the mineral under dietary conditions. Environ. Res. 1983, 31, 245-255. [CrossRef]

49. Dodson, R.; Atkinson, M.A.L.; Levin, J.L. Asbestos fibre length as related to potential pathogenicity: A critical review. Am. J. Ind. Med. 2003, 44, 291-297. [CrossRef] [PubMed]

50. Di Giuseppe, D.; Zoboli, A.; Vigliaturo, R.; Gieré, R.; Bonasoni, M.P.; Sala, O.; Gualtieri, A.F. Mineral Fibres and Asbestos Bodies in Human Lung Tissue: A Case Study. Minerals 2019, 9, 618. [CrossRef]

51. Timbrell, V.; Griffiths, D.; Pooley, F. Possible importance of fiber diameters of South African Amphiboles. Nature 1971, $232,55-56$. [CrossRef] [PubMed]

52. Wylie, A.; Mossman, B. Mineralogical features associated with cytotoxic and proliferative effects of fibrous talc and asbestos on tracheal epithelial and pleural mesothelial cells. J. Toxic Appl. Pharmacol. 1997, 147, 153-160. [CrossRef]

53. Pott, F.; Huth, F.; Friedrichs, K.H. Tumorigenic effects of fibrous dusts in experimental animals. Environ. Health Perspect. 1974, 9 , 313-315.

54. Addison, L.; McConnel, E.E. A review of carcinogenicity studies of asbestos and non-asbestos tremolite and other amphiboles. Regul. Toxicol. Pharmacol. 2008, 52, S187-S199. [CrossRef] [PubMed] 
55. Wylie, A.G.; Bailey, K.F.; Kelse, J.W.; Lee, R.J. The importance of width in asbestos fibre carcinogenicity and its implications for public policy. Am. Ind. Hyg. Assoc. J. 1993, 54, 239. [CrossRef] [PubMed]

56. Riganti, C.; Aldieri, E.; Bergandi, L.; Tomatis, M.; Fenoglio, I.; Costamagna, C.; Fubini, B.; Bosia, A.; Ghigo, D. Long and short fibre amosite asbestos alters at a different extent the redox metabolism in human lung epithelial cells. Toxicol. Appl. Pharmacol. 2003, 193, 106-115. [CrossRef]

57. Wagner, J.C.; Chamberlain, M.; Brown, R.C.; Berry, G.; Pooley, F.D.; Davies, R.; Griffiths, D.M. Biological effects of tremolite. Br. J. Cancer 1982, 45, 352-360. [CrossRef]

58. Berman, D.W.; Crump, K.S. Technical Support Document for a Protocol to Assess Asbestos Related Risk; U.S. Environmental Protection Agency: Washington, DC, USA, 2003.

59. McConnell, E.E.; Axten, C.; Hesterberg, T.W.; Chevalier, J.; Miiller, W.C.; Everitt, J.; Oberdorster, G.; Chase, G.R.; Thevenaz, P.; Kotin, P. Studies on the inhalation toxicology of two fibreglasses and amosite asbestos in the Syrian golden hamster. Part II. Results of chronic exposure. Inhal. Toxicol. 1999, 11, 785-835. [CrossRef] [PubMed]

60. Vallero, D.A.; Beard, M.E. Selecting Appropriate Analytical Methods to Characterize Asbestos in Various Media. Pract. Period. Hazard. Toxic Radioact. Waste Manag. 2009, 13, 249-260. [CrossRef]

61. Mossman, B. Assessment of the pathogenic potential of asbestiform vs. non asbestiform particulates (cleavage fragments) in in vitro (cell or organ culture) models and bioassays. Regul. Toxicol. Pharmacol. 2008, 52, S200-S203. [CrossRef] [PubMed]

62. Mossman, B.T.; Lippmann, M.; Hesterberg, T.W.; Kelsey, K.T.; Barchowsky, A.; Bonner, J.C. Pulmonary endpoints (lung carcinomas and asbestosis) following inhalation exposure to asbestos. J. Toxicol. Environ. Health Part B Crit. Rev. 2011, 14, 76-121. [CrossRef] [PubMed]

63. Chatfield, E. A Procedure for Quantitative Description of Fibrosity in Amphibole Minerals. In Proceedings of the ASTM Michael E. Beard Asbestos Conference, San Antonio, TX, USA, 28-29 January 2012.

64. Belardi, G.; Vignaroli, G.; Trapasso, F.; Pacella, A.; Passeri, D. Detecting asbestos fibres and cleavage fragments produced after mechanical tests on ophiolite rocks: Clues for the asbestos hazard evaluation. J. Mediterr. Earth Sci. 2018, 10, 63-78. [CrossRef]

65. Stayner, L.; Kuempel, E.; Gilbert, S.; Hein, M.; Dement, J. An epidemiological study of the role of chrysotile asbestos fibre dimensions in determining respiratory disease risk in exposed workers. Occup. Environ. Med. 2008, 65, 613-619. [CrossRef]

66. Loomis, D.; Dement, J.M.; Wolf, S.H.; Richardson, D.B. Lung cancer mortality and fibre exposures among North Carolina asbestos textile workers. Occup. Environ. Med. 2009, 66, 535-542. [CrossRef] [PubMed]

67. Loomis, D.; Dement, J.; Richardson, D.; Wolf, S. Asbestos fibre dimensions and lung cancer mortality among workers exposed to chrysotile. Occup. Environ. Med. 2010, 67, 580-584. [CrossRef] [PubMed]

68. Loomis, D.; Dement, J.M.; Elliott, L.; Richardson, D.; Kuempel, E.D.; Stayner, L. Increased lung cancer mortality among chrysotile asbestos textile workers is more strongly associated with exposure to long thin fibres. Occup. Environ. Med. 2012, 69, 564-568. [CrossRef] [PubMed]

69. Cavariani, F.; Marconi, A.; Sala, O. Asbestos: Sampling, analytical techniques and limit values. Arch. Issues 2010, 1, 18-28.

70. Militello, G.M.; Sanguineti, E.; Yus González, A.; Mantovani, F.; Gaggero, L. The Concentration of Asbestos Fibres in Bulk Samples and Its Variation with Grain Size. Minerals 2019, 9, 539. [CrossRef]

71. Perkins, R.L.; Harvey, B.W. Method for the Determination of Asbestos in Bulk Building Materials; U.S. Environmental Protection Agency EPA/600/R-93/116; EPA (Environmental Protection Agency), Office of Research and Development: Washington, DC, USA, 1993.

72. National Institute for Occupational Safety and Health (NIOSH). Method 7400, Asbestos and other fibres by PCM. In NIOSH Manual of Analytical Methods, 4th ed.; DHSS (NIOSH) Pub. No. 2003-154; NIOSH: Cincinnati, OH, USA, 2003.

73. National Institute for Occupational Safety and Health (NIOSH). Method 7402: Asbestos by TEM. In NIOSH Manual of Analytical Methods (NMAM), 4th ed.; NIOSH: Cincinnati, OH, USA, 2003.

74. Gualtieri, A.F. Mineral Fibres: Crystal Chemistry, Chemical-Physical Properties, Biological Interaction and Toxicity; Mineralogical Society of Great Britain and Ireland: London, UK, 2017; Volume 18, p. 536. ISBN 9780903056656.

75. Harper, M.; Lee, E.G.; Slaven, J.; Bartley, D. An inter-laboratory study to determine the effectiveness of procedures for discriminating amphibole asbestos fibres from amphibole cleavage fragments in fibre counting by phase-contrast microscopy. Ann. Occup. Hyg. 2012, 56, 645-659. [CrossRef]

76. Agence Nationale de Sécurité Sanitaire (ANSES). Opinion of the French Agency for Food, Environmental and Occupational Health \& Safety. In Health Effects and the Identification of Cleavage Fragments of Amphiboles from Quarried Minerals; Request No. 2014_SA_0196; Agence Nationale de Sécurité Sanitaire (ANSES): Paris, France, 2015.

77. AHERA (Asbestos Hazardous Emergency Response Act). Interim Transmission Electron Microscopy Analytical MethodsMandatory and Non-Mandatory-And Mandatory Section to Determine Completion of Response. Fed. Regist. 1987, 52, 41857-41897.

78. Harris, K.E.; Bunker, K.L.; Strohmeier, B.R.; Hoch, R.; Lee, R.J. Discovering the True Morphology of Amphibole Minerals: Complementary TEM and FESEM Characterization of Particles in Mixed Mineral Dust; Modern Research and Educational Topics in Microscopy; Méndez-Vilas, A., Díaz, J., Eds.; RJ Lee Group, Inc.: Monroeville, PA, USA, 2007.

79. Van Orden, D.R.; Lee, R.J.; Allison, K.A.; Addison, J. Width distributions of asbestos and non-asbestos amphibole minerals. Indoor Built Environ. 2009, 18, 531-540. [CrossRef] 
80. Hwang, J.; Ramachandran, G.; Raynor, P.C.; Alexander, B.H.; Mandel, J.H. The Relationship Between Various Exposure Metrics for Elongate Mineral Particles (EMP) in the Taconite Mining and Processing Industry. J. Occup. Environ. Hyg. 2014, 11, 613-624. [CrossRef] [PubMed]

81. Hesterberg, T.W. Comments on NIOSH asbestos roadmap-Animal bioassays. In Proceedings of the Workshop on the NIOSH Research Roadmap on Asbestos Fibres and Other Elongated Mineral Particles, Washington, DC, USA, 30 March 2009; National Institute of Occupational Safety and Health: Washington, DC, USA, 2009. 